\title{
Analysis of the scientific production on renewable energies within the framework of sustainability in Mexico
}

\section{Análisis de la producción científica sobre las energías renovables en el marco de la sostenibilidad en México}

\author{
LÓPEZ-XELO, Hilario†*, LUNA-NEMECIO, Josemauel and HERNÁNDEZ-MEDINA, José Juan \\ Instituto Tecnológico Superior de Tlaxco, México \\ Centro Universitario CIFE, México
}

ID $1^{\text {st }}$ Author: Hilario, López-Xelo / ORC ID: 0000-0001-6597-6598

ID $1^{\text {st }}$ Co-author: Josemauel, Luna-Nemecio / ORC ID: 0000-0002-6850-3443

ID $2^{\text {nd }}$ Co-author: José Juan, Hernández-Medina / ORC ID: 0000-0003-4625-2660

DOI: $10.35429 / J R E .2021 .14 .5 .8 .13$

Received March 30, 2021; Accepted June 30, 2021

\begin{abstract}
With the turn of the 20th century to the 21 st, the urgent need to carry out a critique of the current techno-energy pattern, which is based on the intensive use of fossil fuels, becomes more evident. Derived from this productive, energy and material consumption of gas and oil, the conditions have been generated for the configuration of an environmental crisis. In such a way that, there is an urgent need to carry out research that explores the various alternative sources of energy that today appear as an alternative to reduce the negative impact of industrial, agro-industrial and urban activities on the environment. This paper reflects on the problems that exist in Mexico around the development and marginal adoption of renewable energies as a productive source. While $91.2 \%$ of energy in Mexico is produced by burning fossil fuels, it can be established that the energy structure in Mexico is unsustainable. For this reason, a change in energy thinking based on efficiency and sustainability is required, considering both as axes for the use of renewable energies. The goals of the article are: 1) to present a context study, analyzing the production of electrical energy with fossil sources in Mexico, alluding to the difficulty of the transition towards the use of renewable energies. Second, the production of renewable energies in the country is analyzed to find out if investment in them is sustainable.
\end{abstract}

Energy, Renewable, Sustainable

\begin{abstract}
Resumen
Con el paso del siglo XX al XXI, se hace más evidente la urgente necesidad de realizar una crítica al patrón tecnoenergético actual, que se basa en el uso intensivo de combustibles fósiles. Derivado de este consumo productivo, energético y material de gas y petróleo, se han generado las condiciones para la configuración de una crisis ambiental. De tal manera que, es urgente realizar una investigación que explore las diversas fuentes alternativas de energía que hoy se presentan como una alternativa para reducir el impacto negativo de las actividades industriales, agroindustriales y urbanas sobre el medio ambiente. Este trabajo reflexiona sobre los problemas que existen en México en torno al desarrollo y adopción marginal de las energías renovables como fuente productiva. Si bien el $91.2 \%$ de la energía en México se produce mediante la quema de combustibles fósiles, se puede establecer que la estructura energética en México es insostenible. Por ello, se requiere un cambio de pensamiento energético basado en la eficiencia y la sostenibilidad, considerando a ambos como ejes para el uso de energías renovables. Los objetivos del artículo son: 1) presentar un estudio de contexto, analizando la producción de energía eléctrica con fuentes fósiles en México, aludiendo a la dificultad de la transición hacia el uso de energías renovables. En segundo lugar, se analiza la producción de energías renovables en el país para saber si la inversión en ellas es sostenible.
\end{abstract}

Energía, Renovable, Sustentable

Citation: LÓPEZ-XELO, Hilario, LUNA-NEMECIO, Josemauel and HERNÁNDEZ-MEDINA, José Juan. Analysis of the scientific production on renewable energies within the framework of sustainability in Mexico. Journal Renewable Energy. 2021. 514: $8-13$

*Correspondence to Author (e-mail: hil_lx@ @otmail.com)

$\dagger$ Researcher contributing as first author. 


\section{Introduction}

Renewable energies are presented as a factor that would allow to face the accelerated arrival to the ecological limits of the planet (Rockström, 2009). To address the current environmental crisis, the development of technologies that allow the generation of energy without any immediate environmental effect must be promoted. In this sense, it is important to highlight the importance of the so-called renewable energies (RE) in order to advance towards social development based on sustainability. The growth rate of RE use and its increasing trend within world energy markets bears a marked similarity to the appearance of nuclear energy in the 1970s and 1980s. (Estrada Gasca, 2013). However, unlike the first, the latter do not represent a socio-environmental risk, while the direct and indirect dangers of their development and use do not have under them the threat of a catastrophe such as the one that occurred in Chernobille (1986) or in Fukushima (2011).

The serious environmental crisis, the depletion of resources and the imbalances between the Global North and South, are factors that force a new energy policy to be undertaken (Santamarta, 2004). The transformation of the world energy system is to develop new energy policies that consider a low-carbon economy, through strategies that can dispense with the use of fossil fuels to protect the environment. All alternative sources to the use of fossil fuels for power generation are located as RE that have a lower ecological impact; an example of these are: wind, solar radiation, moving water, natural gas, bagasse and other plant residues. It should be clarified that although these alternative sources of energy can be used as fuels for the generation of electricity with a lower environmental cost than the use of gas, coal or oil, this does not represent that in themselves they are considered as energies that in their entirety they are sustainable.

The abuse in the use of non-renewable resources to generate energy has had great environmental impacts and on the health of the population. The use of fossil fuels has negatively impacted the intensive generation of greenhouse gases, which are considered one of the main causes of air pollution and of the climate crisis that is currently in force (Aguilar-Virgen, 2009).
The agenda defined for sustainability in the Brundtland Report (1987) is a report that confronts and contrasts the position of current economic development together with that of environmental sustainability, with the purpose of analyzing, criticizing and rethinking globalizing economic development policies. , recognizing that the current social progress is being carried out at a very high socio-environmental cost.As technology advances and natural resources are depleted, the concern is focusing on how to do the least possible damage to our environment, both in productive terms and in the material and energy inputs that are required to start the automatic system of machines that are required for the production, circulation and consumption of merchandise throughout the world market. Hence, it is important to consider that the development of renewable energies is an element that will allow solving the great challenges of sustainability in the immediate future (Santamarta, 2004)

RE have aroused growing interest as they are considered as inputs obtained from nature with a low ecological cost in reference to the high availability of the natural resource. (Estrada Gasca, 2013). However, it is important to mention that RE have an ecological impact, as in the work of (Quintana, 2018) mentions that the wind farm in Istmo de Tehuantepec (La Ventosa), brings consequences to the environment of the region for not having made a study for its installation.

Fossil fuels are distinguished from RE sources by the time it takes for the energy to be transformed to its final application. Oil, coal, and natural gas were slowly formed by the degradation of organic matter in prehistoric times, defining them as non-renewable or fossil. In contrast to this, solar energy can be directly transferred to electricity (Hehrenheim, 2018).

The total annual solar energy that reaches the Earth's surface and its atmosphere is 2,895,000 EJ / year (7,000 times the global demand in 2004, DG), which represents about 9 times the total resource of all other nonrenewable energies, estimated at 325,300 EJ (770 times the DG). As shown in Table 1 


\begin{tabular}{|l|c|}
\hline Energy source & \multicolumn{1}{|c|}{ Production } \\
\hline Petroleum & 8,690 EJ ( 20 DG) \\
\hline Gas & 17,280 EJ ( 40 DG) \\
\hline Uranium & 114,000 EJ ( 270 DG) \\
\hline Coal & 185,330 EJ ( 440 DG) \\
\hline
\end{tabular}

Table 1 Non-renewable energy production by type of Energy source

Source: Estrada Gasca (2013)

Solar energy in its direct and indirect manifestations together with geothermal energy are also known as renewable energies, that is, energy sources that due to their quantity in relation to the consumption that human beings can make of them are considered inexhaustible. In Mexico, the generation of renewable energy with alternative technologies is low, only $3.5 \%$ of primary energy production uses these renewable resources and the use of hydrocarbons is maintained as the main resource for their generation (Romo, 2013). This shows that not even $40 \%$ of natural resources are used to produce clean energy as in Germany, Costa Rica, China, Norway, which are one of the main countries that produce renewable energy. It is evident that the electricity sector has a relevant role in the fight against the climate crisis, which legitimizes the use of various environmental management instruments to accelerate the energy transition towards non-fossil sources and promote renewables in order to generate clean electricity. The target estimates for the generation of this type of renewable energy establish that in 2018 it should be $25 \%$, by 2021 $30 \%$ and it was estimated that by 2015 it would be $20 \%$ (Correa, 2018).

Our study aims to analyze the scientific production about renewable energies in relation to sustainability in Mexico "for the period 20132019, based on the research carried out in Scopus and WoS where the information published with the highest impact factor is found., in order to evaluate the production of scientific literature that serves as a basis to give a point of view to the feasibility and growth of the generation of renewable energies in Mexico.

\section{Methodology}

A documentary study was carried out, which is a reflective, systematic process, which in turn integrates other processes, with the aim of obtaining new knowledge and explanations of the object (Bernal, 2015). The purpose of this procedure is to obtain new knowledge of what the authors say about the topic to be investigated.
Documentary research becomes more relevant if the information to be analyzed is in large quantity, since it is a way of knowing the different contributions of the authors on the same topic and knowing how those contributions contribute. (Mangua, 2020). De Pro and Rodríguez (2011), state that it is necessary to be able to answer four essential questions within a research work, firstly, who is being investigated ?; second, what is being investigated ?; third, how is the research being conducted ?; and, fourthly, what are the conclusions that are being reached? This to have a clarity about the phases of the investigation and what is being sought and generate some positive change on the subject that is being worked on.

To begin the investigation, 3 phases are proposed, the first is the search for publications made in specialized scientific journals. The second phase consists of carrying out an information dump to consolidate the essential words of each of the publications; and the third consists of the analysis of the articles to discern the information, to verify if each article fulfills the purpose of this work.

In the first phase of searching for articles in the Google Academic, WoS, Science Direct, Scielo, Redalyc and Latindex databases, the search algorithm was used in Spanish: ("renewable energy" OR "sustainable energy" OR "generation" OR "Sustainable energy" OR "environment") AND ("friendly energy" OR "ecological" OR "alternative energy").

In English ("Renewable energy" OR "sustainable energy" OR "generation" OR "sustainable energy" OR "environment") AND ("friendly energy" OR "ecological" OR "alternative energy"), the search was made, they were selected Only articles from indexed journals, the journals were selected taking into account their impact factor on the dissemination of scientific knowledge, of which they comprise the period 2015-2019, the documents should address some element of the essential words to be taken into account .

For phase two, a database is built for its study, which is described in Table 2. 


\begin{tabular}{|l|r|r|r|r|}
\hline Documents & \multicolumn{1}{c}{$\begin{array}{c}\text { About } \\
\text { the } \\
\text { topic }\end{array}$} & \multicolumn{1}{c|}{$\begin{array}{c}\text { Contextualization } \\
\text { or complement }\end{array}$} & \multicolumn{1}{c|}{$\begin{array}{c}\text { From } \\
\text { other } \\
\text { countries }\end{array}$} & \multicolumn{1}{|c|}{$\begin{array}{c}\text { From } \\
\text { other } \\
\text { regions }\end{array}$} \\
\hline $\begin{array}{l}\text { Theoretical } \\
\text { articles }\end{array}$ & 30 & 5 & 10 & 11 \\
\hline $\begin{array}{l}\text { Empirical } \\
\text { articles }\end{array}$ & 30 & 4 & 5 & 31 \\
\hline Books & 3 & 1 & 2 & 2 \\
\hline
\end{tabular}

Table 2 Documents Analyzed in the Study

For the third phase, the filters were used to obtain specific data from all the articles obtained. With which Table II was filled.

To which it was possible to carry out the analysis of the didactic contribution of the articles, and thus, reach the objective of knowing the subject of alternative energies in the didactics of science.

\section{Results}

After conducting a rigorous documentary review of the articles published in journals that are in the Scopus and WoS databases, a total of 60 articles were found that meet the proposed search criteria, according to this information, You can say that if you do research on renewable energy, which is why the idea that scientific research in Mexico is outstanding.

To find out how much importance Mexico gives to scientific research in the area of renewable energies, a search is made in the Scimago Journal Rank (SJR) (http://www.scimagoir.com/), a tool for the evaluation of universities and institutions around the world that prioritize research. It is an indicator developed by the SCImago research group that shows the visibility of the journals contained in Scopus since 1996.

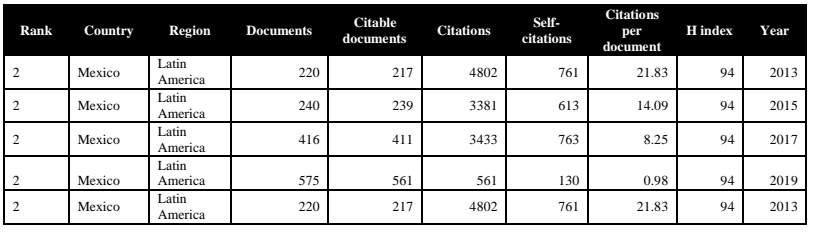

Table 3 Documents published in Scimago Journal Rank for the year 2013-2020 in Mexico

Information is requested on the thematic area of Energy, in the category of Renewable energy, sustainability and the environment, within the Latin American region, in the period 2015 to 2019, the results that the platform shows us are as follows.
Table 3 indicates that the study on the thematic area of energy and on the category of renewable energy, sustainability and environment, has been increasing from 2013 to 2019 , we are a country that cares about this issue in what refers to scientific research, but it does not mean that we are the second country in the implementation of this type of energy generation.

Given that the study presented here only provides elements of theoretical analysis on renewable energies in Mexico, it is necessary to advance in the quantification and application of research so that we can analyze the costs and efficiency that it would bring to the national electricity supply, The second part is to analyze the implementation of regulatory mandates and incentives for the application of renewable energies; This requires determining the attributes of the techno-economics of the system.

\section{Conclution}

The state of approach to the topic of renewable energies in scientific research during the 20132019 period was concluded, through a documentary analysis and scientific publications made in the Scopus and WoS databases. The analysis focused specifically on RE, thus, it was found that renewable energies were addressed mainly from micro-scale laboratories.

There is a marked trend towards scientific research on renewable energies, but it is not implemented. In this way we can say that the importance and potential of engineering degrees, to work on the issue of renewable energy in order to contribute to a change of thought based on action, environmental awareness and sustainability, come from educational centers, so that young people are concerned with improving renewable resources.

In addition to the above, it is essential to begin to spread the advantages of transmitting and distributing electrical energy that is created by means of renewable energies, and this will lead us to large industrial companies consider producing clean and sustainable energy as a profitable option. 
The answer to the question if renewable energy is feasible, if it is, as one of the most solid solutions to mitigate the current planetary environmental crisis, and as seen in this research, there is a lot of information, it is only to take the practical part to be able to provide a solution to our environmental problem.

\section{References}

Adrián, L. G. (2015). Análisis de insumoproducto de energía y observaciones sobre el desarrollo sustentable, caso mexicano 19702010. Ingeniería, investigación y tecnología, 16(2), 239- 251.

Amado-Correal, J. A., Barrera-García, P. A., \& Guzmán-López, J. F. (2021). Implicaciones económicas, sociales y ambientales del uso de energías renovables no convencionales en el sector agrícola colombiano.

Aguilar-Virgen, Q., Armijo-de Vega, C., \& Taboada-González, P. (2009). El potencial energético de los residuos sólidos municipales. Ingeniería, 13(1), 59-62.

Bernal Suarez, D., Martinez Pineda, M. L., \& Parra Pineda, A. Y. (2015). Investigación documental sobre calidad de la educación en instituciones educativas.

Bonilla, C. S., \& Cordero, J. M. (n.d.). La dimensión jurídica de la energía eléctrica y las energías renovables en México. https://doi.org/10.18601/21452946.n22.12

Borbolla-Gaxiola, C., \& Ávila-Ramírez, D. C. (2021). Principales conflictos entre la política de vivienda sustentable y las metas de transición energética en México. El caso del programa Hipoteca Verde. Quivera Revista de Estudios Territoriales, 23(1), 111-130.

Case, M. (2015). Análisis de insumo-producto de energía y observaciones sobre el desarrollo sustentable, caso mexicano 1970-2010. Ingeniería, Investigación y Tecnología, 16(2), 239-251.

https://doi.org/10.1016/j.riit.2015.03.008
Correa L, Gabriela. (2018). Medio ambiente y generación de energía en México. Issn 18706800 .

Chahartaghi, M., Energía, M. S.-, \& 2019, undefined. (n.d.). Evaluaciones energéticas, ambientales y económicas de un sistema CCHP impulsado por un motor Stirling con helio e hidrógeno como gases de trabajo. Elsevier. Retrieved November 26, 2020, from https://www.sciencedirect.com/science/article/p ii/S0360544219304165

de Pro Bueno, A. J., \& Moreno, J. R. (2011). La investigación en la Didáctica de las Ciencias Experimentales. Educatio Siglo XXI, 29(1), 129-148.

De Jesús Ramos-Gutiérrez, L., \& MontenegroFragoso, M. (2012). La generación de energía eléctrica en México. Tecnologia y Ciencias Del Agua, 3(4), 197-211.

Estrada Gasca, C. A. (2013). Transicion energetica, energias renovables y energia solar de potencia. Revista Mexicana de Física, 59(2), 75-84.

http://www.redalyc.org/articulo.oa?id=5703097 1010

Humberto, B.-álvarez, Claudia, G., Rodolfo, S., \& Pablo, S.-álvarez. (2015). Consumo de energía y emisiones de bióxido de carbono del sector refinación de petróleo en México de 2015 a 2030 Energy Consumption and Carbon Dioxide Emissions from Petroleum Refining. Ingeniería, Investigación y Tecnología, 16(4), 503-513.

https://doi.org/10.1016/j.riit.2015.09.003

Juárez, E. M. (2021). Mapa de ruta bio jet en México: construcción, análisis y puntos de reflexión. CIENCIA ergo-sum, 28(1).

La dimensión jurídica de la energía eléctrica y las energías renovables en México. (2019). 299333. SENER 2018

Mangua Guamialamag, L. L. (2020). Energías alternativas en la investigación en didáctica de las ciencias. Análisis documental de la producción científica iberoamericana: 20002019. 
Mohammadnia, A., Rezania, A., \& Ziapour, B. (2020). Sistema de recolección de energía híbrida para maximizar la generación de energía a partir de energía solar. Conversión de Energía Y.https://www.sciencedirect.com/science/articl e/pii/S0196890419313597

Nehrenheim, E. (2018). Introduction to Renewable Energy. https://doi.org/10.1016/B978-0-12-8096659.09138-2

Quintana, R. D. (2018). Política gubernamental vs. política pública: avatares de los parques eólicos en el Istmo de Tehuantepec. Problemas del desarrollo, 49(194), 91-117.

Rockström, J., Steffen, W., Noone, K., Persson, Å., Chapin, FS, Lambin, EF, ... y Foley, JA (2009). Un espacio operativo seguro para la umanidad. naturaleza , 461 (7263), 472-475.

Santamarta, J. (2004). Las energías renovables son el futuro. World Watch, 22(3440.16).

Salerno, P. (2021). Mercado eléctrico y energías renovables. Estudio comparado entre España y México tras las últimas reformas legislativas en materia.

UMYSHEV, D., \& DYUSSEMBEKOVA, N. (2019). Análisis de la posibilidad de utilizar plantas de energía solar sobre la base del motor Stirling en Kazajstán. Revista. http://www.revistaespacios.com/a19v40n27/14 02719.html 